\title{
Between Utopianism and Realism: The Limits of Partisanship as an Academic Methodology ${ }^{1}$
}

\author{
Richard Bellamy, Department of Political Science, University College, \\ London (UCL)
}

\begin{abstract}
Taking debates about democracy in the EU as an example, Fabio Wolkenstein proposes that normative theorists should adopt a 'partisan' approach that engages with 'formative agents' to advocate for transformative political and societal change, such as the creation of a transnational democracy at the EU level. He criticises those he calls 'democratic intergovernmentalists' for adopting a 'first principles' approach that forecloses both contestation and political agency by treating the principles underlying the status quo as universal. This comment disputes both the validity of his criticisms of the work of myself and others, and the coherence of the particular partisan approach motivating them. At its heart, lies a dispute as to the relationship between facts and principles, and the possibility of a utopian realism of the Rawlsean kind. It is argued that Rawls's position proves more democratic and plausible and possesses greater critical and political leverage than Wolkenstein's partisanship alternative.
\end{abstract}

Keywords: facts and principles, utopian realism, partisanship, democracy, European Union

In his critical engagement with some of my work on the European Union (EU) in Political Studies and elsewhere, Fabio Wolkenstein (2018, 2019a and $2019 \mathrm{~b}$ ) advocates the adoption of a partisan approach to normative theorising about politics. So far as the future governance of the EU is concerned, this approach involves engaging with the different views of 'formative agents' in the debate about the EU's democratic legitimacy, and seeking to advance those views (or that view) that can be best portrayed, in formal terms at least, as promoting the general interest of European citizens. One can see this approach as being in some sense an attempt to marry ideal theory to a realist account of political agency, thereby providing a normatively defensible and ostensibly plausible route to the achievement of an ideal future utopia in the real circumstances of a non-ideal world.

While attractive sounding in the abstract, I shall argue that, as practiced by Wolkenstein at least, the partisan approach risks mischaracterising those it critiques, while - its alleged democratic and 
realist credentials notwithstanding - being both elitist and moralistic, with little prospects of practical success. Although I dispute below his characterisation of my own work and question the attractiveness of his alternative, underlying our disagreement is an important and more general debate concerning the relationship of normative theory to empirical research in the social sciences, and how both connect to political practice. At issue is how far normative schemes for changing the world can be separated from empirical attempts to understand it, particularly given those empirical accounts are themselves liable to be to some degree value laden as a result of both reflecting certain normative choices on the part of the social scientist concerned and reporting the normative commitments of those studied. I start by outlining this general context and its place in EU studies, before turning to our different approaches- defending myself along the way from certain of his criticisms.

The EU as a Realistic Utopia - From a Normative to a Partisan Turn in EU Studies?

As with many other hot topics in contemporary political philosophy, the current debate about how far the normative ideals political philosophers propose should be shaped by the empirical social circumstances to which they might be applied took off from certain remarks on this issue by John Rawls (1999a: 7-9, and see Valentini 2012 for a useful overview, with Cohen 2003 making the initial critique focussed on similar sentiments in Rawls 1999b: 137-39). Rawls characterised his account of what he called the Law of Peoples as a realistic Utopia. It was both realistic and utopian in two related respects. First, it originated from critical reflection on the norms underlying current real practices and seeks to extend them in an ideal direction. Second, in so doing, it promoted 'an achievable social world' that nonetheless 'extends what are ordinarily thought of as the limits of practical possibility' (Rawls 1999a: 6).

Rawls regarded this mix of the real and the ideal as not only pragmatically warranted for political philosophy to have any purchase on the world as it is, but also morally warranted because, for reasons I explore more fully in the third section below, it involved treating the views and valued practices of our fellow men and women with a degree of respect, rather than regarding ordinary people as the manipulable subjects of our favoured theories, to be socially engineered to reach our preferred goal. Nonetheless, he was well aware that any attempt to delineate the 'practically possible' involved a degree of 'conjecture and speculation' (Rawls 1999a:12). Meanwhile, as David Miller - who is 
broadly sympathetic to Rawls' approach - has noted, such exercises raise the problem of how 'to know which of these facts [about human behaviour and institutions] to treat as parameters that our theory of justice must recognize, and which to regard as contingencies that the theory may seek to alter.' As he elaborates:

If the theory abstracts too far from prevailing circumstances, it is liable to become a merely speculative exercise, of no practical use in guiding either our public policy or the individual decisions we make as citizens. If the theory assumes too much by way of empirical constraints, on the other hand, it may become excessively conservative, in the sense of being too closely tied to contingent aspects of a particular society or group of societies, and therefore no longer able to function as a critical tool for social change. (Miller, 2007: 18-19)

These difficulties have long dogged EU studies. Given the ongoing and evolving nature of the integration process, the EU has been work in progress from the start. Nevertheless, both practitioners and scholars have tended to assume that the end point of the EU could be broadly inferred from the processes they deemed to have conditioned the integration process thus far. The key debate, therefore, has lain in divisions as to the precise nature of the process - most particularly between neo-functionalists and liberal intergovernmentalists, although other theories abounded. Yet, to some degree all these accounts have involved a leap of faith, based on a belief in the normative as well as the instrumental or functional desirability of a particular mode of integration. Jacques Delors admitted as much when, as one of the prime agents of the step change in the integration process begun with Maastricht, he felt compelled to leave the precise future character of the EU somewhat open, denoting it an as yet 'unidentified political object' (Delors 1985).

However, that was a leap that was contentious at the time and has aroused an increasingly vocal dissensus on the part of a significant number of citizens ever since, not least given the major crises of the Eurozone post 2008, the struggle to accommodate increased migration, and Brexit. These crises have rendered the future course of the EU both more contested and harder to predict, yet at the same time all the more urgent to secure (Bellamy and Castiglione 2019: 1- 4, 435-40).

As Dario Castiglione and I noted back in 2003, given the openended character of the integration process, empirical analysis of the EU has been obliged to take 'a normative turn' (Bellamy and Castiglione 2003 - reproduced as ch. 2 of Bellamy and Castiglione 2019). For, political scientists cannot avoid mixing an element of prescriptive advocacy as to where the EU should be heading within the various 
descriptive accounts they offer of where they believe it is going. Even the soberest and most realistic empirical analyses of the EU tend to involve an idealistic and utopian (or dystopian) element. As more normative theorists have turned their attention to the EU, including a brilliant younger generation of scholars of whom Wolkenstein is one, a parallel question arises as to how far normative analysis of the EU should be obliged to take 'an empirical turn'. Either way, as I note in Bellamy 2019: 16-17, both the empiricist and the normative camp face the two problems identified by Rawls and Miller reported above: namely, how much is the empirical view of where the EU headed based on mere 'conjecture and speculation', and to what extent are the normative positions they implicitly or explicitly advocate either too ideal to be either pragmatically feasible or morally acceptable, or too real to amount to anything more than a justification of the status quo.

Normative theorising about the EU has often taken the form of applying normative accounts of global justice and the prospects for cosmopolitan democracy to the EU (e.g. Habermas 2012), including engaging directly with the Rawlsean position (Rawls and Van Parijis 2003; Bellamy 2019 ch 1; Van Parijis 2019). However, although the methodological debates discussed above have figured widely in this literature (Ypi 2010), studying a real case renders the degree to which idealised theoretical models can be action guiding without taking into account (and being challenged and modified by) certain empirical features of actually existing reality that much sharper (Bellamy and Castiglione 1998, reproduced in Bellamy and Castiglione 2019 as ch. 1). Moreover, as the EU has become increasingly politicised, so - at least implicitly, and often explicitly - have the choices theorists may make.

Does that mean that normative theorising about the EU cannot avoid partisanship? And if so, how far - and in what ways - should the political choices involved be a matter of the theorist's own individual political judgment or should they incorporate the views of democratic publics as well? And what are the results of doing the latter rather than the former? Is the division really between those mobilising support for their utopia of a better future and those stuck in the past and defending the current reality and the prejudices of those who inhabit it as the best we can achieve? As I noted above, Wolkenstein tends to portray himself as being in the former camp with myself, possibly unwittingly and contrary to my intentions, belonging to the latter. Yet, just as he seeks to argue that his own partisan idealism can be nonetheless grounded in the real politics of opinion formation, so I regard my work as being not only grounded in the realities of current EU politics but also as an ideal programme of reforms for the future (Bellamy 2019: 15-20). He finds this Rawlsean advocacy of a realistic Utopia inherently unstable and so difficult to 
grasp. I believe his incomprehension derives from the partisan rejection of the present as necessarily immersed in the past, with the future only accessible by way of a clean break. Yet, to be action guiding, normative ideals have to engage with the present, and hence also with the past.

Wolkenstein claims that I adopt a form of argumentation whereby citizens are 'relegated to passive recipients of normative standards thought to be independently valid' (Wolkenstein 2019a: 1). As I shall attempt to show below, I think the opposite is the case. I am engaging in a project of democratic persuasion - my audience is, in principle, fellow citizens as well as scholars of the EU. On this view, it becomes important to recognise reasonable disagreements about the $\mathrm{EU}$, and to engage with other positions fairly to try and show that one's preferred theoretical stance can accommodate the interests, concerns and deeply held values of others. By contrast, Wolkenstein's mode of argument is directed to a vanguardist political movement of 'formative agents' - it is essentially Leninist, concerned with bringing about a future whose legitimacy derives from its being supported by a given ideal of justice. Yet, this kind of partisan approach leads precisely to treating citizens as 'passive recipients of normative standards thought to be independently valid'. I also think it explains a tendency to consistently misread my work and that of others. I turn next to these partisan misreadings before returning to the more general debate of how a utopian realism can be both principled and democratic.

\section{Partisan Critiques}

Wolkenstein has at different times suggested that I am committed to 1) a general triggering of Article 50 by all member states as a result of idealising the nation state in a form that is no longer achievable in the existing EU (Wolkenstein 2018), and - somewhat contradictorily - of adopting 2) what he calls a 'first principles' approach to theory building to defend what he calls 'democratic intergovernmentalism' (Wolkenstein 2019a). Somewhat surprisingly given my supposed advocacy of dismantling the EU and starting afresh, he also claims my work reflects 3) a 'common, perhaps even the dominant, response in recent normative scholarship' (Wolkenstein 2019a: 2) to the crisis of the Euro area and the issue of how the EU might be made more democratic.

I do not recognise my views in any of these critiques. The first and third criticisms can be straightforwardly disputed, telling though they are of his approach. The supposed commitment to a general exit from the EU comes from his contention that 'it is difficult to see how popular sovereignty at the domestic level could otherwise be achieved' given the 
'unprecedented expansion of European integration in the post-Maastricht period' (Wolkenstein 2018: 291). He makes this assertion to rebut my 'moral costs' argument against a shift of democratic authority upwards to the supranational level by claiming that the costs of instituting a 'demoicratic' vision of the EU would be as great, if not greater. However, although the two articles he mainly uses to discuss my arguments were written before the Brexit referendum of 2016, I make clear in both (Bellamy 2013: 504-06; 2017: 203-04) that there is not only a functional need but also a moral obligation for states to enter into an association such as the EU in order to maintain a feasible and justified form of popular sovereignty at the domestic level. Only within such an association can states avoid various externalities and secure certain public goods, on the one hand, and respect the democratic autonomy of different polities and provide equal opportunities to their citizens, on the other (for elaboration, see Bellamy 2019: 4-6). Moreover, having defined the criteria an appropriate association of democratic states needs to meet to be consistent with my theory of 'republican intergovernmentalism' (Bellamy 2013: 507), I then offer a detailed account of how the EU as it currently exists can be aligned in formal terms with these criteria (Bellamy 2013: 507-10; 2017: 205-06), and discuss problems - notably the Eurocrisis - that might stand in the way of its continuing to do so in the future (Bellamy 2013: 510-514). Of course, all of this may be contestable and he could be right that the EU has passed the point where demoi-cracy of the kind I advocate is possible. But, given all the evidence I put forward to suggest otherwise, I do not think the contrary view can simply be asserted in half a sentence and supported by references to works by two of the very few academic analysts of the EU favourable to Brexit - Chris Bickerton (et. al. 2015) and Wolfgang Streeck (2015), whose views on the current constraints and prospects of reforming the EU are somewhat narrower than most mainstream scholarship. In sum, his claim that breaking up the EU and starting afresh is 'the most realistic strategy' for realising my preferred scenario seems questionable and overly 'partisan'.

A similarly partisan approach marks his claim that I am a leading representative of the 'dominant' school of normative theorising about the EU. It is true that I have been influenced by, and partly align myself with, the 'demoi-cratic' and 'multilateral democracy' approaches of Kalypso Nicolaïdis (2013) and Francis Cheneval (2011) respectively, and he can plausibly treat the three of us as members of a 'demoicratic' school of thought in Wolkenstein 2018: 285. However, as he acknowledges, my view is explicitly intergovernmental in a way their theories are not. He does cite Miriam Ronzoni's 2017 article suggesting that their 'third way' between intergovernmentalism and federalism may not be 
achievable but, contrary to his account, she (rightly, I think) places Nicolaïdis and Cheneval more on the federal side of the equation than myself.

In Wolkenstein 2019a he unaccountably drops Nicolaïdis - the founding and leading figure of this school of thought - and adds Fritz Scharpf (2009) and Deirdre Curtin (misspelt throughout as Curtain) as allies of a 'democratic intergovernmental' approach. However, Scharpf (2015: 399-400) has been sceptical of the demoicratic perspective. Meanwhile, Curtin - represented only by an article from 2014 - is perhaps best known among normative theorists for her 1997 book advocating 'postnational democracy', based on the sort of transnational, civil society movements Wolkenstein himself endorses. Moreover, she has been a prominent critic of the way intergovernmental bargaining has produced fragmented treaties that fail to treat all EU citizens in a uniform way (Curtin 1993). Unsurprisingly, my school of one can hardly be regarded as 'dominant'. As with the broader debate on cosmopolitan or global democracy, I would hazard a guess that the supra- and transnational approaches are more dominant. Certainly, they have the support of much more prominent political philosophers than I, such as Habermas (2012) and Van Parijis (2019).

These misrepresentations prove important because they frame his second criticism of my approach as constructed on the basis of 'first principles'. He claims that I develop a 'stipulated normative account of the relevant component parts of democratic legitimacy', such as 'people' or 'sovereignty', and then deduce my view of the EU so as to fit my putatively 'universal' account of these concepts (Wolkenstein 2019a: 6), so that 'it is hardly surprising that Bellamy concludes from this that "popular sovereignty presupposes state sovereignty" (Wolkenstein 2019b: 879 quoting Bellamy 2019: 72). However, such an approach would render my concerted engagement with supranational and transnational views somewhat mysterious. This feature of both Bellamy 2017 and 2019 (of which 2017 forms chapter 3) is not mentioned in any of his discussions of my work, but gives the lie to his assertion that Bellamy 'presents his account of legitimacy ... as essentially exempt from reasonable disagreement' (Wolkenstein 2019a: 6). Precisely because my view goes against the current, rather than being dominant, I feel the need to defend and compare it to the main, and rather more prominent, competitors (as indeed I announce in Bellamy 2019: 4). In particular, I accept features of the cosmopolitan and globalist critique of statist theories and try to show how their concerns could be met by a theory that takes national sovereignty seriously (Bellamy 2019: 6). For example, the sentence he quotes as an 'unsurprising' conclusion of my argument actually appears at the start of the chapter on sovereignty 
(Bellamy 2019: 72; and of Bellamy 2017: 189) as a declaration of my purpose to defend what many, including it would seem Wolkenstein, might find indefensible. It is done knowing that most will find the argument 'surprising'.

\section{Utopian Realism: Between Facts and Principles}

At the heart of his misunderstanding would appear to be confusion on his part as to the role principles play in my account and their relation to facts. Although he accuses me of a 'lack of clarity' on this issue (Wolkenstein 2019b: 879), I am explicit about closely following the account of Rawls in The Law of Peoples (Rawls 1999a: 11-12; Bellamy 2019: 15-20). Let me try and clarify this position some more.

Some of Wolkenstein's misunderstanding appears to arise from a failure to distinguish three different types of principle. First, there is the Rawlsean distinction between a concept and its different conceptions (Rawls 1999b: 5). He sees my attempts to outline the concept of democracy or sovereignty as stipulative and not allowing for disagreement and change. However, the disagreement is surely about rival conceptions of the concept, rather than over the concept itself. If there was no agreement on the concept, our disagreements about its interpretation and applicability would simply talk past each other. In fact, his main disagreement appears to be with my conception of the 'demos', which he sees as biased towards the location of democracy at the national level and as ruling out the possibility of either a trans- or supra- national democracy. However, I do not rule out this disagreement as a matter of definitional fiat, say by claiming those seeking a form of democracy beyond the nation state have committed some kind of category mistake. On the contrary, I engage at length in chapters 3, 4 and 5 of Bellamy 2019 with the ways Bohman (2004 a and b), Habermas (2012) and others have attempted to re-define the demos in post-national ways that might accommodate a transnational or supranational democracy. I simply disagree with them and offer arguments - which others may take issue with - as to why one should regard these attempts as being comparatively speaking empirically and normatively defective. Likewise, his gripe seems not to be with the concept of sovereignty as I define it as such, but whether it remains important or not and can likewise be located at a different level or dispensed with entirely - again arguments I discuss in dedicated sections of Bellamy 2017 and 2019 ch. 3.

A further distinction arises when turning to the normative assessment of the different conceptions of democracy beyond the state and my own alternative vision of 'inter-national' demoi-cracy via a non- 
sovereign association of sovereign states. This distinction is between what Samuel Freeman (2009, in response to Cohen 2003) has called 'justificatory' principles, such as Rawls's ideal of free and equal persons, and principles of 'right conduct', such as Rawls's two principles of justice. I do put justificatory principles first, yet so does Wolkenstein, but see principles of right conduct as fact dependent in a number of ways that he disputes.

Wolkenstein gives a rather formal version of such a justificatory principle: on his account, partisanship is normatively acceptable to the extent that partisans adopt a "non-partial approach to the whole"" and 'seek to exercise power "in view of a general interest"" (Wolkenstein 2019a: 11). Rawls's (1999b) 'Original Position' - a version of which is employed by Cheneval (2011), follows a similar pattern, in being constructed so as to treat all individuals as free and equal persons, and to employ justificatory constraints of universality, publicity and so on. My own justificatory principle is that any legitimate political regime or policy must be 'non-dominating', a requirement that involves similar constraints to the justifying reasons Rawls (and Wolkenstein) employ. It provides the criterion in Bellamy 2013 and Bellamy 2017 as well as Bellamy 2019, where I defend its use in chapter 2 as a criterion to justify my own proposal and assess those of supra- and trans-nationalists in the rest of the book.

This shared, if limited, first principles approach is not a top down stance in my, Rawls' and Cheneval's case any more than in Wolkenstein's but a democratic one, because the purpose in all three cases is to ensure an inclusive form of justification. However, when it comes to devising principles of right conduct and their applications, in this case principles of political justice, I follow Rawls in regarding them as being fact dependent, and so as not coming first, in two basic ways (see Miller 2012: 29-35, also responding to Cohen 2003). First, such principles presuppose certain features of the human condition - basically those Rawls (1993: 54-8) associates with what he calls the 'fact of pluralism' and the related 'burdens of judgement', that, following Jeremy Waldron (1999: 159-60) I argue give rise to the 'circumstances of politics'. Unless these facts characterised human societies, principles of political justice would be irrelevant. Second, and more controversially, such principles should not only respect what we know about human biology and the physical world, and so not be practically impossible, but also respect the considered judgments of those to whom they are to apply as to what is tolerable and justifiable.

With regard to the latter and perhaps also the former of these factual grounds for principles of political justice, Wolkenstein thinks I give too much weight to the status quo. Note, though, that cannot be 
because I put principles first, but rather because he thinks my reasoning involves principles coming second to facts that he considers can be changed by convincing people of an alternative set of principles. In other words, in this regard he puts principles first as the motivating ideals of a partisan movement. With regard to the first grounding given above, it is certainly possible to conceive of a world beyond the 'circumstances of politics', where - as Engels put it - the 'government of persons' is replaced by the 'administration of things' (Engels 1878: Part 3, ch. 2). Yet, conceivable does not mean feasible or even likely. Such a shift would appear to require an absence of a plurality of perspectives and a unity of views that Gramsci, one of the heroes of the partisan approach (White and Ypi 2010), acknowledged as 'totalitarian', although he used the term in a putatively 'positive' sense (Gramsci 1977: 800). However, the limits of practical reasoning adverted to by Rawls suggests such attempts to go beyond politics will in practice always be totalitarian in the negative sense as well. Here the 'moral loss' argument seems unavoidable.

The second type of factual grounding might be thought more questionable. Most theorists would acknowledge that people's attitudes change along with their circumstances, often for the better. So why prioritise current judgments, no matter how widely shared - especially if they may amount to no more than popular prejudices? There are three main reasons that render this exercise valid. First, to be taken into account, such judgments would need to be compatible with the aforementioned justificatory principle. It is for that reason that I advocate a cosmopolitan statism rather than statism tout court (Bellamy 2019: ch 1). Second, justifiable facts of this kind place a normative feasibility constraint on what we can propose. They explain why we should avoid the 'moral loss' of wishing away institutions that play a valuable part in people's lives. Take the family, for example (Miller 2012: 32-33). Clearly, we can conceive of a society without families. Moreover, such a society might in ideal terms be more apt to promote a desirable principle such as equality of opportunity. Yet, most people would regard the abolition of the family as an intolerably high price to pay to realise an ideally just society, given family life itself has many morally valuable features. That does not mean that one cannot seek to render families more just, such as by abandoning the traditional gendered division of labour within them, or work to mitigate certain unfair biases in their influence on the life chances of children, for example through a well-funded and appropriately organised public system of education. Perhaps more controversially, I argue - as noted above - that similar claims can be made about existing state-based political communities. While abolishing these would likewise involve a 'moral loss', their internal and external 
functioning can be realistically reformed to produce a fairer and less dominating system of international justice and democracy that accommodates and promotes cosmopolitan norms. Third, one can regard the normative aligning of principles of political justice with the core beliefs of those to whom they are to apply as a democratic process (Miller 2012: 34, Rawls 1999a: 128). It involves acknowledging the likely partiality of one's own views and the need to treat the views of one's fellow citizens with equal concern and respect, rather than as somehow less principled and progressive than one's own.

All three of these reasons involve adopting a 'realistic utopia' and attuning one's ideals to social facts, including the opinions of one's fellow citizens, a process Rawls characterises as a search for 'reflective equilibrium' (Rawls 1999b: 18-19). Note, that - contrary to Wolkenstein's claims - this process involves neither acceptance of the status quo nor a refusal to consider alternatives, since reflective equilibrium means that any principle can only be applied in the context of being contested, questioned, and applied to empirical reality (Bellamy 2019: 18). By contrast, Wolkenstein's partisan approach can be criticised for reasons that parallel these three points.

First, while we can readily identify retrospectively the progressive formative agents of the past, such as the suffragettes, it is harder to do so prospectively. Moreover, although Wolkenstein's formal principle of justification rules out backing some groups, such as the Tea Party, it is too weak to exclude others he disagrees with. The neo liberals of the Mont Pelèrin Society, for example, might argue that their policies can further the common good more than socialist policies will. To counter such possibilities, he must either put more stringent principles first, or, more implausibly, commit to knowing - or have faith in - the principled direction of history.

Second, he admits that 'transforming the identities of the citizens of the EU Member States ... will inevitably be a long-term endeavour, spanning perhaps even across multiple generations.' (Wolkensetin 2018: 292). Yet, working for a putatively ideal future by supporting congenially minded groups, such as the DiEM25 movement - that managed at most $3 \%$ and in general less than $1 \%$ of the vote in most states in the recent European elections - comes at the cost of comparative impotence so far as addressing issues in the present is concerned.

Third, it is elitist rather than democratic, prioritising the role of 'formative agents' to mould the views of the masses to fit the principles he regards as correct. It is democratic in the manner of the 'democratic centralism' of the Leninist vanguard party. It is not democratic in the sense of accepting the need to build coalitions among people who may agree to disagree but subscribe all the same to a number of cross-cutting 
goals, including mutual respect for their differences. It is this latter view of democracy that nonetheless animates demoi-crats.

\section{Conclusion}

I put principles first only to the extent Wolkenstein's partisan view does that is, in applying justificatory principles. Indeed, he goes further through assuming his principles of right conduct are somehow inscribed in the movement of history. Moreover, by importing partisan politics into academic scholarship, his approach also becomes less democratic towards colleagues and citizens. He reproaches me for not engaging with formative agents such as public intellectuals, like Habermas, or key figures of EU supranational politics, who take a different view of democracy in the EU to mine. In fact, that is incorrect - chapter 1 of Bellamy 2019: 27-30 sets the scene precisely through an engagement with Habermas, on the one hand, and von Rompuy and Barroso, on the other, and this on-going engagement informs much of the book (e.g. 8387, 118-19, 147-68). Indeed, that engagement goes back to my earliest writings on the EU post- Maastricht (Bellamy and Castiglione 2019: Introduction). However, I have also wanted to note that their views are often out of kilter with those of the vast majority of citizens, with the current anti-EU backlash a predictable result. Moreover, in the republic of letters as in politics more generally, no one school of thought or single individual is likely to have a monopoly on truth, let alone on the course of history. As a result, it behoves one to be aware of the partial character of one's own views and engage with those of others in a non-partisan way that acknowledges that truth may be plural and complex. That does not mean I do not have strong opinions of my own, but these have developed through open dialogue with others, and involve a degree of mutual accommodation. By contrast, if one chooses to go the vanguardist route, then that is likely not only to be anti-democratic but also to involve sacrificing scholarly standards as well. If the value of scholarship is reduced to its political effects, to just being a weapon in a political struggle directed to an end whose justice is determined in advance, then we are in the domain of scholarship as polemic.

\section{References}

Bellamy, R. (2019) A Republican Europe of States: Cosmopolitanism, Intergovernmentalism and Democracy in the EU, Cambridge: Cambridge University Press. 
Bellamy, R. (2017) A European Republic of Sovereign States:

Sovereignty, Republicanism and the European Union', European Journal of Political Theory, 16. 2: 188-209

Bellamy, R. (2013). 'An Ever Closer Union of Peoples: Republican Intergovernmentalism, Demoi-cracy and Representation in the EU', Journal of European Integration, 35(5): 499-516.

Bellamy, R. and Castiglione, D (2019), From Maastricht to Brexit: Democracy, Constitutionalism, and Citizenship in the EU, Rowman and Littlefield/ECPR Press.

Bellamy, R. and Castiglione, D. (2003). 'Legitimising the Euro-polity and its Regime: The Normative Turn in EU Studies', European Journal of Political Theory, 2(1): 7-34.

Bellamy, R. and Castiglione, D. (1998) 'The Normative Challenge of a European Polity: Cosmopolitanism and Communitarianism Compared, Criticised and Combined' in A. Follesdal and P. Koslowski (eds.) Democracy and the EU, Berlin: Springer-Verlag, pp. 254-80.

Bickerton, C., Hodson, D. and Puetter, U. (2015) 'The New Intergovernmentalism: European Integration in the Post-Maastricht Era', Journal of Common Market Studies, 53.4: 703-22.

Bohman, J. (2004a). 'Republican Cosmopolitanism', Journal of Political Philosophy, 12(3): 336-52.

Bohman, J. (2004b). 'Constitution Making and Institutional Innovation: The European Union and Transnational Governance', European Journal of Political Theory, 3(3): 315-37.

Cheneval, F. (2011) The Government of the Peoples: On the Idea and Principles of Multilateral Democracy, New York: Palgrave Macmillan

Cohen, G. A. (2003) 'Facts and Principles', Philosophy and Public Affairs, 31.3: 211-45.

Curtin, D. (1997) Postnational Democracy the European Union in Search of a Political Philosophy, The Hague: Kluwer Law International

Curtin, D. (1993) 'The Constitutional Structure of the Union: A Europe of Bits and Pieces' Common Market Law Review, 30.1: 17-69 
Curtin, D. (2014) 'Challenging Executive Dominance in European Democracy’, Modern Law Review 77:1: 1-32

Delors, J. (1985) Speech, Luxembourg 9 September, http://www.cvce.eu/obj/speech_by_jacques_delors_luxembourg_9_septe mber_1985-en-423d6913-b4e2-4395- 9157-fe70b3ca8521.html

Engels, F. (1878) Anti-Dühring. Herr Eugen Dühring's Revolution in Science, Progress Publishers, 1947

Freeman, S. (2009) 'Constructivism, Facts and Moral Justification', in T. Christiano and J. Christman (eds), Contemporary Debates in Political Philosophy, Oxford: Blackwell, 41-60

Gramsci, A. (1977) Quaderni del carcere, 4 vols, ed. V Gerratana, Turin: Einaudi

Habermas, J. (2012). The Crisis of the European Union: A Response, Cambridge: Polity Press.

Miller, D. (2012) Justice for Earthlings: Essays in Political Philosophy, Cambridge: Cambridge University Press

Miller, D. (2007) National Responsibility and Global Justice, Oxford, Oxford University Press.

Nicolaïdis, K. (2013). 'European Demoicracy and its Crisis', Journal of Common Market Studies, 51(2): 351-369

Rawls, J. (1993). Political Liberalism, New York: Columbia University Press

Rawls, J. (1999a). The Law of Peoples, Cambridge, MA: Harvard University Press.

Rawls, J. (1999b) A Theory of Justice. Revised Edition. Cambridge, MA: Belknap Harvard, 1971.

Rawls, J. and Van Parijs, P. (2003). 'Three Letters on The Law of Peoples and the European Union', Revue de philosophie economique 7: 7-20 
Ronzoni, M. (2017) 'The European Union as Demoi-cracy. Really a Third Way?’ European Journal of Political Theory, 16 (2): 210-234

Scharpf, F.W. (2009). 'Legitimacy in the Multilevel European Polity', European Political Science Review, 1(2): 173-204

Scharpf, F.W. (2015). 'After the Crash: A perspective on Multilevel European Democracy', European Law Journal, 21(3): 384-405

Sleat, M. (2016) Realism, Liberalism and Non-ideal Theory Or, Are there Two Ways to do Realistic Political Theory? Political Studies, 64 (1): 27-41

Streeck, W. (2015) 'Heller, Schmitt and the Euro', European Law Journal, 21.3: 361-70.

Valentini, L. (2012) 'Ideal vs Non-ideal Theory: A Conceptual Map', Philosophy Compass, 7 (9), 654-64

Van Parijis, P. (2019) “Just Europe', Philosophy and Public Affairs (early view)

Waldron, J. (1999). Law and Disagreement, Oxford: Oxford University Press.

White, J. and Ypi. L (2010), 'Rethinking the Modern Prince: Partisanship and the Democratic Ethos', Political Studies, 58.4: 809-828

Wolkenstein, F. (2018) 'Demoicracy, Transnational Partisanship and the EU', Journal of Common Market Studies 56.2: 284-99.

Wolkenstein, F. (2019a) 'The Revival of Democratic Intergovernmentalism, First Principles and the Case for a Contest-Based Account of Democracy in the European Union', Political Studies (early view): 1-18.

Wolkenstein, F. (2019b) Review of A Republican Europe of States: Cosmopolitanism, Intergovernmentalism and Democracy in the EU, By Richard Bellamy, Perspectives on Politics, 17(3): 879-80.

Ypi, L. (2010). 'On the Confusion between Ideal and Non-ideal in Recent Debates on Global Justice', Political Studies 58(3): 536-55. 
${ }^{1}$ I am grateful for the helpful comments on an earlier version by Dario Castiglione, Francis Cheneval, Glyn Morgan and especially Albert Weale, as well as the extremely insightful and useful report of a referee for this journal. 